\title{
The evolution of nesting behaviour in Peromyscus mice
}

\author{
Caitlin L. Lewarch and Hopi E. Hoekstra
}

Department of Organismic and Evolutionary Biology,

Department of Molecular and Cellular Biology,

Museum of Comparative Zoology, Howard Hughes Medical Institute, Harvard University, Cambridge,

MA 02138 USA

\author{
Corresponding Author: \\ Hopi Hoekstra \\ Biological Labs \\ 16 Divinity Ave \\ Cambridge, MA 02138 \\ (617) 496-9040 \\ hoekstra@oeb.harvard.edu
}




\section{$1 \quad$ ABSTRACT}

2 Structures built by animals, such as nests, often can be considered extended phenotypes that facilitate

3 the study of animal behaviour. For rodents, nest building is both an important form of behavioural

4 thermoregulation and a critical component of parental care. Changes in nest structure or the

5 prioritization of nesting behaviour are therefore likely to have consequences for survival and

6 reproduction, and both biotic and abiotic environmental factors are likely to influence the adaptive

7 value of such differences. Here we first develop a novel assay to investigate interspecific variation in the

8 nesting behaviour of deer mice (genus Peromyscus). Using this assay, we find that, while there is some

9 variation in the complexity of the nests built by Peromyscus mice, differences in the latency to begin

10 nest construction are more striking. Four of the seven taxa examined here build nests within an hour of

11 being given nesting material, but this latency to nest is not related to ultimate differences in nest

12 structure, suggesting that the ability to nest is relatively conserved within the genus, but species differ in

13 their prioritization of nesting behaviour. We also find that latency to nest is not correlated with body

14 size, climate, or the construction of burrows that create microclimates. However, the four taxa with

15 short nesting latencies all have monogamous mating systems, suggesting that differences in nesting

16 latency may be related to social environment. This detailed characterization of nesting behaviour within

17 the genus provides an important foundation for future studies of the genetic and neurobiological

18 mechanisms that contribute to the evolution of behaviour.

21 Key words: behavioural evolution, comparative method, deer mice, extended phenotype

22 Running head: Evolution of nesting behaviour 


\section{INTRODUCTION}

Animal architectures - from the webs spun by spiders to the dams built by beavers - can both facilitate the study of behaviour and provide insight into the selective forces at that act on behavioural variation (Hansell, 1984, 2005). Such structures can be considered "extended phenotypes," or traits influenced by genetics but extended outside the body of the individual organism (Dawkins, 1982). been used for classification purposes in insects and some birds (Hansell, 1984; Knerer et al., 2012; Schmidt, 1964; Winkler et al., 1993). These structures reflect stereotyped patterns of behaviour and the neural circuits that generate these motor patterns, allowing us to study behaviour and the nervous system by proxy. Moreover, the structures themselves serve important functions and can confer readily quantifiable fitness benefits on the animals that construct them (Hayward, 1965; Mainwaring et al., 2014; Sealander, 1952).

A widespread and important type of building behaviour is the collection and processing of environmental materials to produce a nest. Nests serve a wide variety of purposes for the animals that construct them. For small-bodied animals, such as rodents, nests provide insulation and reduce the energy expended on the maintenance of body temperature (Pearson, 1960; Sealander, 1952; Vogt \& Lynch, 1982). In animals with altricial young, like many birds and rodents, nests are especially critical to

41 protect offspring from heat loss and predation (Bult et al., 1997; Collias, 1964; Lynch \& Possidente,

42 1978; Southwick, 1955). The nest may even serve as a catalyst for social behaviour - nest and bower construction can be integral to courtship in birds (Mainwaring et al., 2014), and investment in elaborate

44 nests likely has been instrumental in the evolution of eusociality in insects (Hansell, 2005). Depending on

45 the species in question and the environment in which they live, nests may be built in trees, in pre- 
architecture, nests are often separate structures, made by collecting and processing vegetation and other material from an animal's environment.

Both the structure of a completed nest and the timing of nest building may be relevant traits for

51 natural selection, and each has distinct implications for the proximate and ultimate factors that

52 contribute to behavioural differences among taxa. Variation in nest structure, as is observed in birds,

53 suggests that animals may differ either in their ability to construct nests or in the desired properties of

54 their nests (Mainwaring et al., 2014). At the level of proximate mechanism, variation could result from

55 morphological differences in the animals, fundamental changes in their stereotyped motor patterns, or

56 changes in a more abstract encoding of the animal's target structure. Moreover, variation in nest

57 structures suggests that the characteristics of the nest itself have fitness consequences. Prime examples

58 of such relationships include the pendulous entrances of some weaverbird nests, which are protective

59 against snake predation (Collias, 1964; Crook, 1963), or the increased size and weight of robin, warbler,

60 and finch nests built at colder northern versus southern latitudes (Crossman et al., 2011). Variation in

61 the timing of nesting behaviour, on the other hand, implies that animals differ in their motivation to

62 engage in otherwise conserved behavioural patterns, and suggests that the prioritization of nesting

63 relative to other elements of the animal's behavioural repertoire is relevant for selection. Prioritization

64 can occur at different scales, from time invested over the course of a single night to relative time spent

65 on the behaviour during different seasons. As the collection of nesting material can be energetically

66 costly and expose the animal to predation (Collias, 1964; Mainwaring et al., 2014), it may be beneficial

67 for an animal to prioritize other behaviours in environmental conditions where heat loss, for example, is

68 not a pressing concern. While population differences in nest size have been studied within and between

69 species of rodents (King et al., 1964; Lynch, 1992), we do not know how the prioritization of nesting

70 behaviour has evolved. 
To determine how and why these features of nesting behaviour evolve, we focused on deer

72 mice (genus Peromyscus), which have adapted to a wide range of habitats and microhabitats across

73 North America (Bedford \& Hoekstra, 2015; Blair, 1950; Dewey \& Dawson, 2001). Specifically, deer mice

74 live in climates with pronounced differences in winter temperatures (King et al., 1964), vary in body size,

75 a trait associated with adaptation to cold in other rodents (Lynch, 1992), and have distinct social

76 behaviour and parental care (Jašarević et al., 2013; Turner et al., 2010), all of which may affect nest-

77 building behaviour. Importantly, while these species have evolved in different environments, laboratory

78 colonies allow us to perform behavioural experiments under carefully controlled conditions using

79 animals that share a common environment (Bedford \& Hoekstra, 2015). This is therefore an opportunity

80 to explore the evolutionary consequences of different environmental parameters on heritable variation

81 in nest-building behaviour.

82 Here we develop a novel behavioural assay to evaluate natural variation in both ability and

83 motivation to nest in seven species and subspecies of Peromyscus mice. This detailed characterization of

84 thermoregulatory nesting behaviour then provides a foundation to understand the evolution of this

85 behaviour in natural populations.

86

87 METHODS

88 Ethical Note

All experimental procedures were approved by the Harvard University Institutional Animal Care

90 and Use Committee. The animal housing facility in which these tests were performed maintains full

91 AAALAC accreditation.

92

93

Experimental Cohort 
We selected adult, reproductively inexperienced animals of both sexes from seven laboratory

95 colonies of Peromyscus, representing five species, with well-characterized ecology and social systems

96 (Table 1). While these colonies were isolated from natural populations (brought in from the wild

97 between 2 and 71 years ago, depending on strain; Table 1), all animals in this study were born in

98 captivity.

99

Animal Husbandry

All animals were bred and maintained under the same controlled conditions. We kept the

102 animal housing rooms on a $16: 8 \mathrm{LD}$ cycle at $22^{\circ} \mathrm{C}$. We housed animals in ventilated polysulfone mouse

107 (Shepherd Specialty Papers, Watertown, TN), a 0.6cm layer of Anderson's Bed-o-cob (The Andersons,

108 Inc., Maumee, $\mathrm{OH})$, and enrichment consisting of a red polycarbonate $(9.5 \mathrm{~cm} \times 4.8 \mathrm{~cm} \times 7.6 \mathrm{~cm})$ mouse

109 hut (BioServ, Flemington, NJ) or a $15.2 \mathrm{~cm} \times 7.6 \mathrm{~cm}$ inside diameter rat tunnel for the large $P$. californicus

110 animals (BioServ, Flemington, NJ). All animals had ad libitum access to water and irradiated LabDiet

111 Prolab Isopro RMH 3000 5P75 (LabDiet, St. Louis, MO). We socially housed animals in groups of 2-5 by

112 species and sex after weaning (23 days for most species, 30 days for $P$. californicus), then tested them as

113 adult virgins, averaging 2-6 months old (Table 1).

\section{Behavioural Paradigm}

116 Standard Behavioural Assay: Nesting behaviour in rodents is often assessed by measuring the

117 weight of nesting material an animal uses over 24 hours (Hartung \& Dewsbury, 1979; King et al., 1964; 
Table 1: Experimental Cohort

\begin{tabular}{|c|c|c|c|c|c|c|}
\hline $\begin{array}{c}\text { Species } \\
\text { (common name) }\end{array}$ & County Isolated & $\begin{array}{l}\text { Year in } \\
\text { Captivity* }\end{array}$ & $\begin{array}{c}\text { Sample Size } \\
\text { total (males, females) }\end{array}$ & $\begin{array}{l}\text { Avg. Weight, } \\
\text { Males } \\
(\mathrm{g} \pm \mathrm{sd})\end{array}$ & $\begin{array}{l}\text { Avg. Weight, } \\
\text { Females } \\
(\mathrm{g} \pm \mathrm{sd})\end{array}$ & $\begin{array}{l}\text { Avg. Age } \\
\text { (days } \pm \text { sd) }\end{array}$ \\
\hline $\begin{array}{l}\text { P. maniculatus nubiterrae } \\
\text { (cloudland deer mouse) }\end{array}$ & $\begin{array}{l}\text { Westmoreland } \\
\text { County, PA }\end{array}$ & 2010 & $47(31,16)$ & $18.7 \pm 2.3$ & $15.8 \pm 2.8$ & $164 \pm 184$ \\
\hline $\begin{array}{l}\text { P. maniculatus bairdii } \\
\text { (deer mouse) }\end{array}$ & $\begin{array}{c}\text { Washtenaw County, } \\
\mathrm{MI}\end{array}$ & $1946-1948$ & $95(62,33)$ & $20.3 \pm 3.5$ & $16.9 \pm 1.6$ & $106 \pm 50$ \\
\hline $\begin{array}{l}\text { P. polionotus subgriseus } \\
\text { (oldfield mouse) }\end{array}$ & Marion County, FL & 1952 & $130(80,50)$ & $14.3 \pm 1.9$ & $15.5 \pm 1.7$ & $107 \pm 57$ \\
\hline $\begin{array}{c}\text { P. polionotus leucocephalus } \\
\text { (Santa Rosa Island beach } \\
\text { mouse) }\end{array}$ & Okaloosa County, FL & 2015 & $37(23,14)$ & $14.2 \pm 1.1$ & $14.4 \pm 2.7$ & $71 \pm 17$ \\
\hline $\begin{array}{c}\text { P. leucopus } \\
\text { (white-footed mouse) }\end{array}$ & Avery County, NC & $1982-1985$ & $35(22,13)$ & $21.7 \pm 4.1$ & $20.1 \pm 2.7$ & $66 \pm 7$ \\
\hline $\begin{array}{l}\text { P. gossypinus } \\
\text { (cotton mouse) }\end{array}$ & Jackson County, FL & 2009 & $27(19,8)$ & $25.2 \pm 7.0$ & $21.9 \pm 3.3$ & $72 \pm 9$ \\
\hline $\begin{array}{c}\text { P. californicus } \\
\text { (California mouse) }\end{array}$ & Ventura County, CA & $1979-1987$ & $48(25,23)$ & $42.1 \pm 5.2$ & $41.5 \pm 7.0$ & $126 \pm 30$ \\
\hline
\end{tabular}

*Some species were brought into captivity multiple times over several years, see (Bedford \& Hoekstra., 2015). Female maniculatus bairdii animals give birth to their first litter when they are approximately three months old (Bedford \& Hoekstra, 2015), and generation times for other species are similar in the lab. 
Layne, 1969; Lynch \& Hegmann, 1973), which is readily quantifiable but can obscure variation in the

119 timing of the behaviour or the structure of the nests the animals construct. To measure these aspects of nesting behaviour, we designed a novel assay that consists of an overnight habituation period followed

121 by three consecutive days of testing. On the day before a trial began, we weighed and singly housed

122 adult virgin animals in new mouse cages (including $P$. californicus) with $5 \mathrm{~g}$ of compressed cotton nesting

123 material (or two "nestlets", see above), $0.6 \mathrm{~cm}$ layer of Anderson's Bed-o-cob, and a red polycarbonate

124 mouse hut. On the morning following habituation to the novel cage, we took photos of the nest from up

125 to three angles (top and two side views), then removed the mouse hut and replaced all cotton nesting

126 material with $5 \mathrm{~g}$ of fresh compressed cotton nestlet. The replacement of nesting material during these

127 trials always occurred between 4.5 and 6.5 hours after the lights came on. At one hour after the

128 replacement of nesting material, we again took photographs of the nest from multiple angles and added

129 the mouse hut back to the cage. We repeated this process on the following two mornings for a total of

130 three sets of photographs (day 1 , day 2, and day 3 ) at each of the two time points (1h and overnight).

131 Research assistants blinded to the species and sex of the animal later scored these nest photographs

132 according to a standardized scale (Fig. 1; Supplemental Table S1). Scores ranged from 0 (no visible

133 shredding) to 4 (a full "dome" nest with overhead coverage) with only full and half scores given.

Increased Nesting Material: To examine whether the amount of nesting material had an impact on

nest scores in the largest species ( $P$. californicus; approximately $42 \mathrm{~g}$, on average), we modified the

137 nesting experiment in two ways. First, we singly housed an independent cohort of 21 adult $P$.

138 californicus animals as above, but provided them with an increasing amount of cotton nesting material

139 on four consecutive days: $5 \mathrm{~g}$ on day $1,10 \mathrm{~g}$ on day $2,15 \mathrm{~g}$ on day 3 , and $20 \mathrm{~g}$ on day 4 . We photographed

140 nests and exchanged cotton nesting material once every 24 hours, and a research assistant blind to

141 experimental conditions scored these photographs as above to establish whether this increase was 


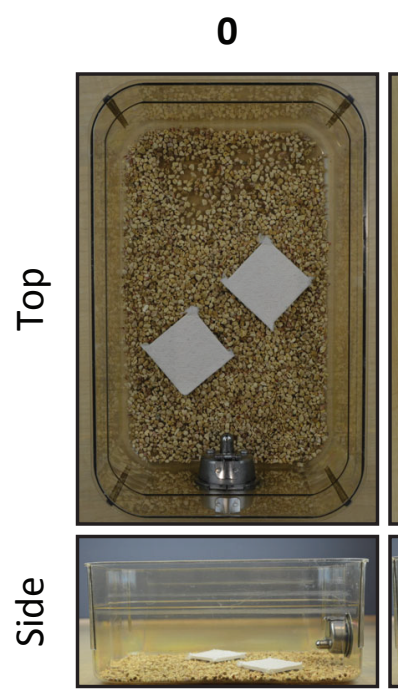

No Nesting
1
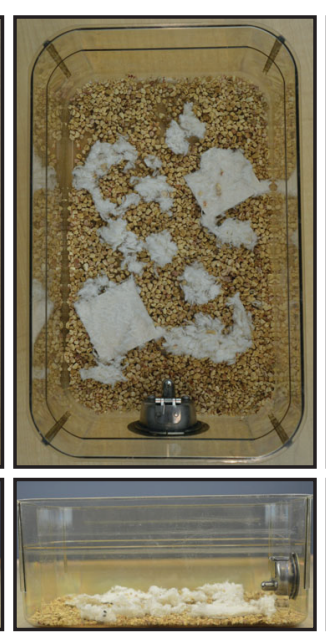

Shredding
2
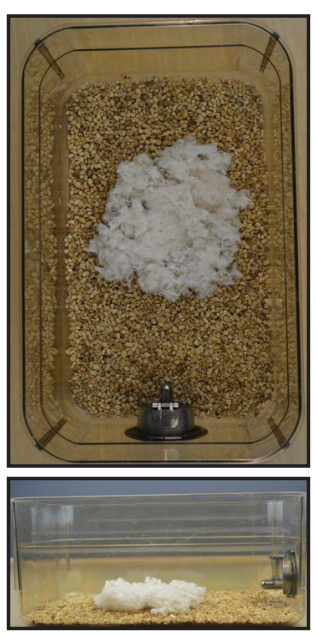

Platform
3
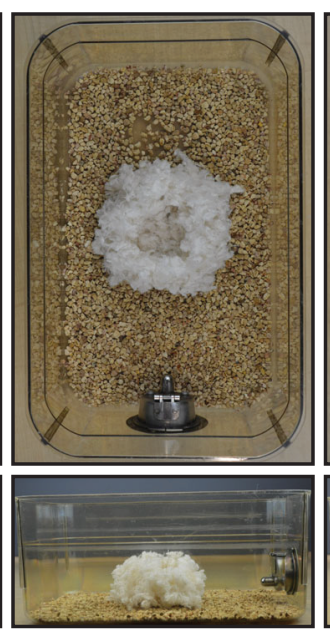

Cup
4

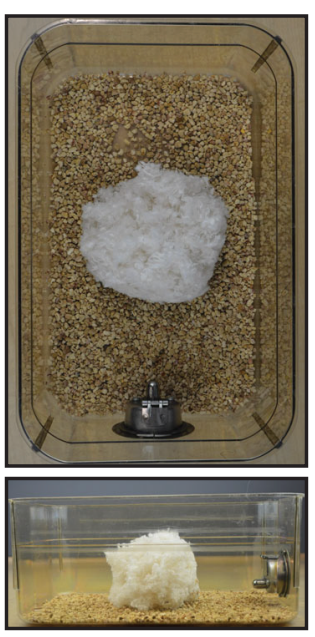

Dome

Figure 1: Nest scoring scale. Nests are scored on a scale from 0 (no manipulation of the nesting material) to 4 (a full cotton "dome") in increments of 0.5 . Representative nests for each of the five integer scores are shown from both the top and side view, and a brief descriptor is provided for each. Classification is according to criteria provided in Supplementary Table S1. 
142 sufficient to alter overnight nest scores. Based on the results of these experiments, we then assayed an

143 independent group of 23 adult $P$. californicus animals to evaluate their overnight nesting behaviour

144 using $20 \mathrm{~g}$ of cotton nesting material in an otherwise standard nesting assay (see "Standard Behavioural

145 Assay" above).

Climate Data

We drew average winter (December/January/February) temperature data from National

149 Oceanic and Atmospheric Administration (NOAA) 30-year climate normals (Arguez et al., 2010), and

150 averaged these data by state or county of origin for each colony (Table 2).

Data Analysis

We performed statistical analyses in R using non-parametric methods for the ordinal nest

154 scores. We summarized an animal's behaviour across the three trial days by its median score (to reflect

155 central tendency) or its maximum score (to represent best effort) at each time point after the

156 replacement of nesting material. To identify differences between groups, we used Kruskal-Wallis rank-

157 sum tests, and then used Bonferroni-corrected Wilcoxon rank-sum tests for subsequent pairwise

158 comparisons between species or sexes. For the experiment that tests the effects of increased access to

159 nesting material in a cohort of $P$. californicus animals, we used a Friedman rank-sum test.

For comparative analyses, we first generated an ultrametric tree using Grafen's method (Grafen,

161 1989; Symonds \& Blomberg, 2014) and the known topology of the species relationships (Fig. 2A; Bedford

162 \& Hoekstra, 2015; Bradley et al., 2007; Weber \& Hoekstra, 2009). To test for a relationship between

163 species-level median $1 \mathrm{~h}$ nest scores and species-level average weights, latitudes of origin, and winter

164 temperatures at sites of origin, we performed phylogenetic generalized least squares (PGLS) analysis

165 using the ape and nlme packages in R (Paradis et al., 2004; Pinheiro et al., 2017; Symonds \& Blomberg, 
Table 2: Environmental Context

\begin{tabular}{|c|c|c|c|c|c|c|c|c|}
\hline Taxon & $\begin{array}{l}\text { Latitude } \\
\left({ }^{\circ} \mathrm{N}\right)^{\mathrm{A}}\end{array}$ & $\begin{array}{l}\text { Avg. } \\
\text { Winter } \\
\text { Temp. } \\
\left({ }^{\circ} \mathrm{C}\right)^{\mathrm{B}} \\
\end{array}$ & Habitat & $\begin{array}{l}\text { Habitat } \\
\text { Use }\end{array}$ & Habitat Ref. & Burrows $^{c}$ & Nest Location & $\begin{array}{l}\text { Mating } \\
\text { System }\end{array}$ \\
\hline $\begin{array}{l}\text { P. } m \text {. } \\
\text { nubiterrae }\end{array}$ & 40.2 & -1.2 & forest & $\begin{array}{l}\text { semi- } \\
\text { arboreal }\end{array}$ & (Blair, 1950) & simple/short & $\begin{array}{l}\text { arboreal; tree cavities (Wolff \& Durr, } \\
\text { 1986; Wolff \& Hurlbutt, 1982) }\end{array}$ & M \\
\hline P. m. bairdii & 42.3 & -3.4 & prairie/grassland & terrestrial & (Blair, 1950) & simple/short & $\begin{array}{l}\text { in burrows (Morris \& Kendeigh, } \\
\text { 1981) }\end{array}$ & $P$ \\
\hline $\begin{array}{l}\text { P. p. } \\
\text { subgriseus }\end{array}$ & 29.2 & 14.4 & sandy soil/grassland & $\begin{array}{l}\text { semi- } \\
\text { fossorial }\end{array}$ & (Blair, 1950) & complex/long & in burrows (Dawson et al., 1988) & M \\
\hline $\begin{array}{l}\text { P. p. } \\
\text { leucocephalus }\end{array}$ & 30.4 & 11.0 & white sand beach & $\begin{array}{l}\text { semi- } \\
\text { fossorial }\end{array}$ & $\begin{array}{l}\text { (Blair, 1950; Sumner, } \\
\text { 1926) }\end{array}$ & complex/long & in burrows (Blair, 1951) & M \\
\hline P. leucopus & 36.1 & 0.9 & deciduous forest & $\begin{array}{l}\text { semi- } \\
\text { arboreal }\end{array}$ & $\begin{array}{l}\text { (Blair, 1950; Lackey } \\
\text { et al., 1985) }\end{array}$ & simple/short & $\begin{array}{l}\text { seasonally dependent; arboreal or } \\
\text { ground nests (Wolff \& Durr, 1986; } \\
\text { Wolff \& Hurlbutt., 1982) }\end{array}$ & $P$ \\
\hline P. gossypinus & 30.7 & 11.3 & $\begin{array}{l}\text { hardwood forest, } \\
\text { mesic hammocks, } \\
\text { swamps }\end{array}$ & $\begin{array}{l}\text { semi- } \\
\text { arboreal }\end{array}$ & $\begin{array}{l}\text { (Wolfe \& Linzey, } \\
\text { 1977) }\end{array}$ & $\begin{array}{l}\text { no laboratory } \\
\text { data }\end{array}$ & $\begin{array}{l}\text { diverse but arboreal preferred; in or } \\
\text { under logs and stumps, in tree } \\
\text { cavities (Ivey, 1949; Klein \& Layne, } \\
\text { 1978; Wolfe \& Linzey, 1977) }\end{array}$ & $P$ \\
\hline P. californicus & 34.1 & 12.3 & scrub/chaparral & $\begin{array}{l}\text { semi- } \\
\text { arboreal }\end{array}$ & $\begin{array}{l}\text { (Clark, 1936; } \\
\text { M'Closkey, 1976; } \\
\text { Merritt, 1978; } \\
\text { Meserve, 1977) }\end{array}$ & none & $\begin{array}{l}\text { under logs, in woodrat (Neotoma) } \\
\text { dens (Merritt, 1974, 1978) }\end{array}$ & M \\
\hline
\end{tabular}

A. Latitude of county of origin (Table 1).

B. 30-year NOAA climate normals for average Dec/Jan/Feb temperatures, pooled by county of origin for each colony (Arguez et al., 2010).

C. Burrows produced in a laboratory assay from (Weber \& Hoekstra, 2009), with the exception of P. m. nubiterrae (Hu \& Hoekstra, 2017).

D. Most likely mating system (Monogamous or Promiscuous) according to (Turner et al., 2010), with the exception of $P$. $m$. nubiterrae (Wolff \& Cicirello, 1991) and $P$. gossypinus (Dewsbury et al., 1980; McCarley, 1959; Pearson, 1953). 
2014). Covariance due to relatedness was modelled by Brownian motion using the corBrownian function

167 in ape. The covariance was then included as a correlation parameter in the generalized least squares

168 analyses in $\mathrm{nlme}$. The effect of each environmental variable on $1 \mathrm{~h}$ nest scores was tested independently.

169 To test whether short nesting latency is dependent on other discrete traits (complex burrowing or

170 mating system, as indicated in Table 2), we performed Pagel's binary character correlation test using the

171 fitPagel function in the phytools package in R (Pagel, 1994; Revell, 2012). For this test, we utilized the

172 fitMk method, allowed all rates of change to be different between states (model="ARD"), and set

173 nesting latency (short vs. intermediate/long) to be dependent on the state of either mating system

174 (monogamous vs. promiscuous) or burrow complexity (complex vs. simple/absent). As there are no

175 laboratory data on burrowing behaviour in P. gossypinus, this species was excluded from the latter

176 analysis.

177

\section{RESULTS}

\section{Interspecific variation in nesting latency}

To measure an animal's motivation to nest, we assayed individuals from seven Peromyscus taxa

181 with known evolutionary relationships (Fig. 2A). First, we analysed the median of the three scores an

182 animal received one hour after the replacement of nesting material, which reflects the tendency of the

183 animal to begin nesting shortly after their nest is disturbed. Scores at $1 \mathrm{~h}$ were significantly correlated

184 across the three days in the full dataset (Spearman rank correlations: day 1 vs. day $2 r_{s}=0.75$, day 1 vs.

185 day $3 r_{\mathrm{s}}=0.68$, day 2 vs. day $3 r_{\mathrm{s}}=0.78, N=419, P<2.2 \times 10^{-16}$ for each), and species comparisons were

186 largely the same whether three-day medians or maxima were used (see below). The median nest scores

187 at $1 \mathrm{~h}$ following the initiation of the trial varied dramatically among the taxa we assayed (Fig. 2B; Kruskal-

188 Wallis test: $\left.H_{6}=216.85, P<2.2 \times 10^{-16}\right)$. Four taxa $(P$. m. nubiterrae, $P$. p. subgriseus, $P$. p. leucocephalus,

189 and $P$. californicus) had high, statistically indistinguishable scores at the $1 \mathrm{~h}$ time point (Supplemental 


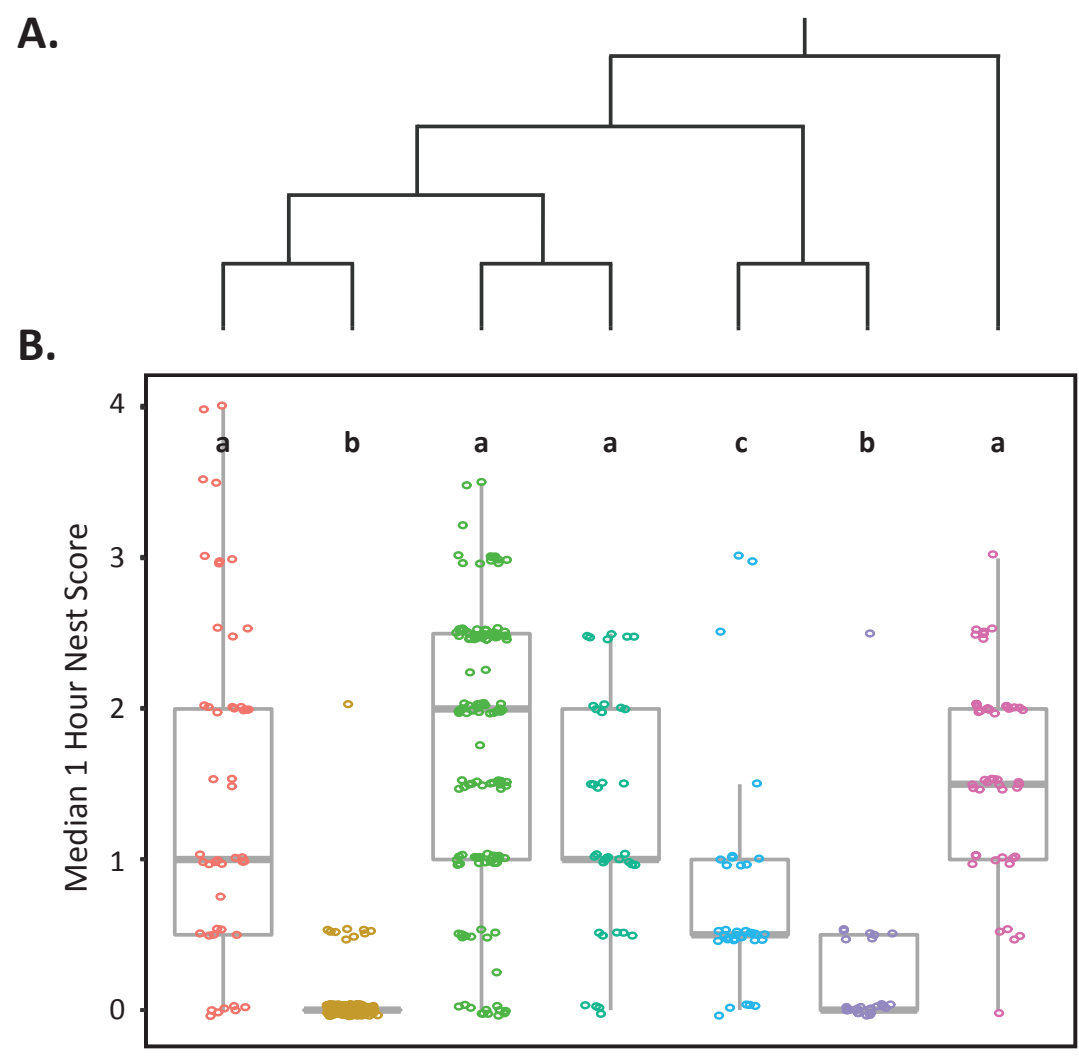

C.

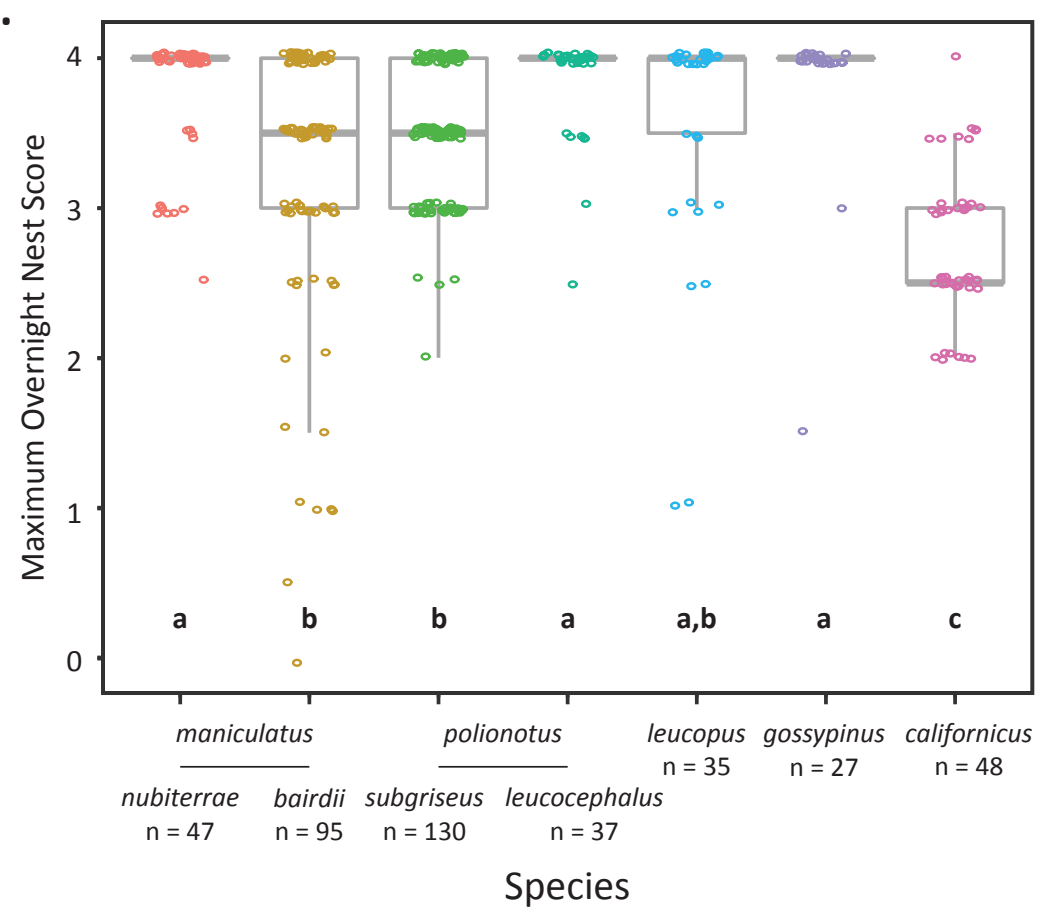

D.

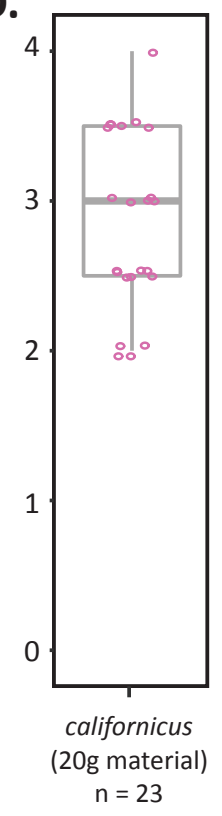

Figure 2: Interspecific differences in nesting behaviour. (A) Phylogenetic relationships among the Peromyscus taxa included in this study; modified from (Bedford \& Hoekstra, 2015; Weber et al., 2009). (B) Median nest scores $1 \mathrm{~h}$ after receiving new nesting material and (C) maximum overnight nest scores for each animal over the 3 trial days. Letters indicate species groups that do not significantly differ from one another, while all other pairwise comparisons are significant (Wilcoxon rank-sum test, Bonferroni-corrected $P<0.05$ ). (D) $P$. californicus animals given $20 \mathrm{~g}$ of nesting material do not differ in maximum overnight scores from those given $5 \mathrm{~g}$ of nesting material (Wilcoxon rank-sum test, $P=0.47$ ). Sample sizes are provided below. 
Table S2, Wilcoxon rank-sum test, Bonferroni-corrected $P>0.05$ for each pairwise comparison),

191 suggesting that they began to construct their nests relatively quickly and progressed past the point of

192 just shredding the material. In addition, these four taxa differed significantly from the other three taxa

193 we assayed (Supplemental Table S2, Wilcoxon rank-sum test, Bonferroni-corrected $p<0.05$ for each

194 pairwise comparison). P. leucopus animals received intermediate scores that reflect a tendency to shred

195 the material, but not arrange it into a nest, at the $1 \mathrm{hr}$ time point. These scores were significantly

196 different from those received by all other species (Supplemental Table S2, Wilcoxon rank-sum test,

197 Bonferroni-corrected $P<0.05$ for each pairwise comparison). Finally, $P$. m. bairdii and $P$. gossypinus

198 animals had equivalently low scores (Supplemental Table S2, Wilcoxon rank-sum test, Bonferroni-

199 corrected $P=0.29$ ), which indicate that they did not manipulate the nesting material in the first hour and

200 suggest that they are relatively slow to initiate nest construction. Ranking of each taxon's performance

201 largely followed the same pattern whether maximum or median nest scores were used (Supplemental

202 Figure S1). The only exception was one species difference: while the median nest scores of $P$. gossypinus

203 and $P$. m. bairdii animals at $1 \mathrm{~h}$ were indistinguishable, $P$. gossypinus were slightly more likely to shred

204 the nesting material on at least one of the trial days and therefore had slightly, but significantly, higher

205 maximum scores (Wilcoxon rank-sum test: $W=839, N_{1}=27, N_{2}=95$, Bonferroni-corrected $P=0.049$ ). We

206 note that taxa differ in the variance of their nest scores: this likely results from within-species variation

207 in nest-building efficiency, time spent nesting, and/or the precise initiation time during the first hour. In

208 sum, based on our analysis of $1 \mathrm{~h}$ median scores, we identified three main groups of nest builders in our

209 assay: those with short, intermediate or long latencies to nest.

\section{Interspecific differences in nesting ability}

We next asked whether these taxa differed in their overall ability to construct a three-

213 dimensional nest. To establish the highest-scoring nest that an animal was capable of producing, we 
used the maximum score achieved over the individual's three overnight time points, which represents

215 the animal's best effort during the longest interval of the trial. Maximum overnight scores varied

216 significantly among taxa (Fig. 2C; Kruskal-Wallis test: $H_{6}=127.21, P<2.2 \times 10^{-16}$ ), although most animals

217 built full or partial domes. The highest scoring nests were consistently constructed by P. m. nubiterrae,

218 P. p. leucocephalus, P. leucopus, and P. gossypinus animals, which tended to build statistically

219 indistinguishable full domes (Supplemental Table S2, Wilcoxon rank-sum test, Bonferroni-corrected

$220 P>0.05$ for each pairwise comparison). Three taxa - P. m. bairdii, $P$. p. subgriseus, and $P$. leucopus - had

221 equivalently high maximum scores (Supplemental Table S2, Wilcoxon rank-sum test, Bonferroni-

222 corrected $P>0.05$ for each pairwise comparison), and $P$. m. bairdii and $P$. p. subgriseus, which tended to

223 build domes with only partial cover, were significantly different from all but $P$. leucopus animals

224 (Supplemental Table S2, Wilcoxon rank-sum test, Bonferroni-corrected $P<0.05$ for each pairwise

225 comparison). Finally, P. californicus animals tended to build nests with walls but without overhead

226 cover, and had significantly lower maximum nest scores than all other species tested (Supplemental

227 Table S2, Wilcoxon rank-sum test, Bonferroni-corrected $P<0.05$ for each pairwise comparison). Notably,

228 we found that all species had at least one individual who constructed a domed nest with full cover

229 (maximum nest score, "4") during the assay, suggesting that all species are capable of building a

230 "complete" nest if given enough time. However, some species showed a large variance in nest scores,

231 and P. californicus tended to have lower maximum scores than the other species.

\section{Nest-building behaviour in the large $P$. californicus mice}

P. californicus animals are much larger than the other taxa included in this study (Table 1), and

235 therefore might require more material to construct a dome nest with overhead cover. To test the

236 possibility that these animals built lower-scoring nests because $5 \mathrm{~g}$ of nestlet was an insufficient amount

237 of nesting material, we conducted two additional experiments. First, we gave a group of $P$. californicus 
animals increasing amounts of nesting material on four consecutive days and evaluated the nests they

239 produced in each 24-hour interval. We found that increasing nesting material from $5 \mathrm{~g}$ to $20 \mathrm{~g}$ could

240 increase overnight nesting scores (Supplemental Fig. S2; Friedman test: $X^{2}{ }_{3}=13.468, p=0.004$ ). However,

241 when we provided an independent group of $P$. californicus animals with $20 \mathrm{~g}$ of nesting material during a

242 three-day trial (Fig. 2D), there was no difference in overnight maximum scores between those $P$.

243 californicus given $5 \mathrm{~g}$ of nestlet and those given $20 \mathrm{~g}$ (Wilcoxon rank-sum test: $W=609, N_{1}=23, N_{2}=48$,

$244 P=0.47)$. Moreover, the maximum overnight nest scores for $P$. californicus given $20 \mathrm{~g}$ of nestlet remained

245 significantly lower than the maximum nest scores for all other species (Supplemental Table S2, Wilcoxon

246 rank-sum test, Bonferroni-corrected $P<0.05$ for each pairwise comparison). Thus, the poor nest

247 construction of $P$. californicus in this assay cannot be attributed simply to insufficient nesting material

248 relative to its large body size.

\section{Sex differences in nesting}

We next investigated whether there were any sex differences in the nest scores produced by each species and subspecies. Only two taxa showed evidence of sexual dimorphism in nesting (Fig. 3).

253 Both male $P$. m. nubiterrae and male $P$. p. subgriseus animals built higher scoring nests than their female

254 counterparts one hour after the start of the assay (Supplemental Table S3, Wilcoxon rank-sum test,

255 Bonferroni-corrected $P=0.03$ and 0.002 , respectively), and $P$. p. subgriseus males also built higher

256 scoring nests at the overnight time point (Supplemental Table S3, Supplemental Fig. S3; Wilcoxon rank-

257 sum test, Bonferroni-corrected $P=0.008)$. No other species showed evidence of sex differences in nest

258 scores at either time point (Supplemental Table S3, Wilcoxon rank-sum test, Bonferroni-corrected $P$

$259>0.05$ for each pairwise comparison). Therefore, while there was no sexual dimorphism in nesting

260 behaviour for most taxa, in both instances when sex differences were observed, males constructed

261 higher-scoring nests than the females. 
bioRxiv preprint doi: https://doi.org/10.1101/177782; this version posted January 27,2018 . The copyright holder for this preprint (which was not certified by peer review) is the author/funder, who has granted bioRxiv a license to display the preprint in perpetuity. It is made available under aCC-BY-NC-ND 4.0 International license.

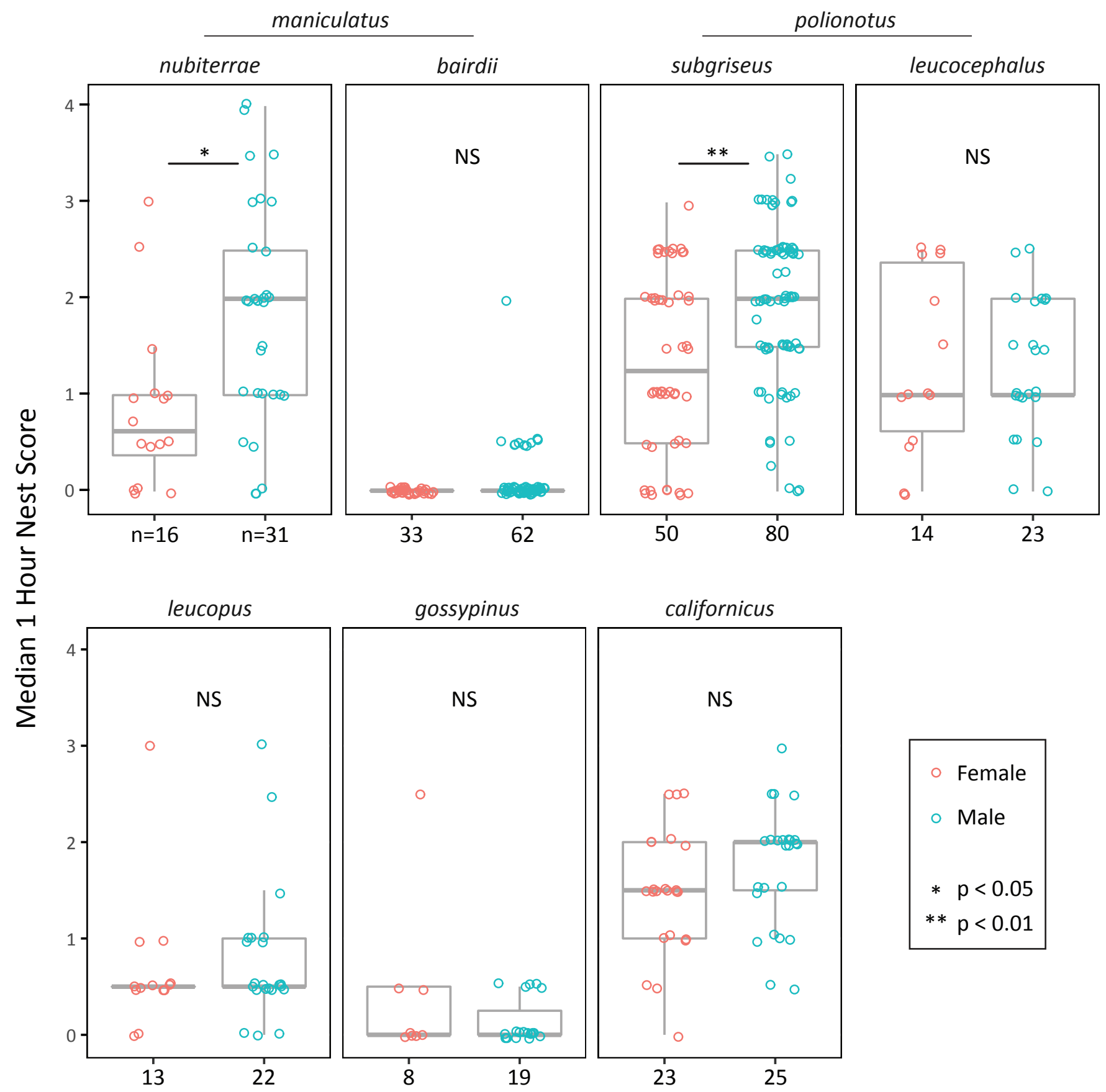

Figure 3: Sex differences in nesting latency. Sex-specific median 1h nest scores for each Peromyscus taxa tested. Significant sex differences in median nest score occurred in only two groups: $P$. maniculatus nubiterrae (Wilcoxon rank-sum test, Bonferroni-corrected $P=0.03$ ) and $P$. polionotus subgriseus $(P=0.002)$. Sample sizes are provided below. NS = non-significant. 


\section{Association between body size and nest building}

To determine whether body size had an effect on nest-building behaviour, we tested for

correlations between weight and performance in the nesting assay. We found that weight significantly

varied by species, sex, and species-by-sex interactions in our experimental cohort (two-way ANOVA,

main effect of species: $F_{6,352}=365.9, P<2 \times 10^{-16}$; main effect of sex: $F_{1,352}=5.3, P=0.02$; interaction: $F_{6,352}$

$=4.1, P=0.0005)$. However, there was no evidence that species-level average weights alter median $1 \mathrm{hr}$

nest scores (Fig. 4A, phylogenetic generalized least squares, median $1 \mathrm{hr}$ nesting score by average

weight: coefficient $=-0.01, \mathrm{SE}=0.06, t=-0.15, P=0.89)$. Likewise, when we divided the animals by species

271 and sex, we found no correlation between weight and median nest score at $1 \mathrm{~h}$ (Supplemental Table S4,

272 Spearman's rank correlations, Bonferroni-corrected $P>0.05$ ) or maximum overnight nest score

273 (Supplemental Table S4, Spearman's rank correlations, Bonferroni-corrected $P>0.05$ ) within any of the

274 species-sex groups. Thus, while average weight varied almost three-fold among species, weight was not

275 associated with nesting behaviour in our assay.

\section{Association between environment and nest construction}

We next asked whether there was an association between performance in the nesting assay and

279 several additional environmental covariates, including latitude and average winter temperature of

280 origin, burrow construction, and mating system. Neither latitude nor average winter temperatures were

281 significantly associated with median $1 \mathrm{hr}$ scores in these species (Table 2, Fig. 4B; phylogenetic

282 generalized least squares, median $1 \mathrm{hr}$ nest score by latitude: coefficient $=-0.05, \mathrm{SE}=0.08, t=-0.71$,

$283 P=0.51$; median $1 \mathrm{hr}$ nest score by average winter temperature: coefficient $=0.03, \mathrm{SE}=0.05, t=0.69$,

$284 \mathrm{p}=0.52$ ). Moreover, nesting latency does not appear to be influenced by burrowing behaviour: a model

285 in which short nesting latency is dependent on building complex burrows does not fit the data 
bioRxiv preprint doi: https://doi.org/10.1101/177782; this version posted January 27,2018 . The copyright holder for this preprint (which was not certified by peer review) is the author/funder, who has granted bioRxiv a license to display the preprint in perpetuity. It is made available under aCC-BY-NC-ND 4.0 International license.

A.
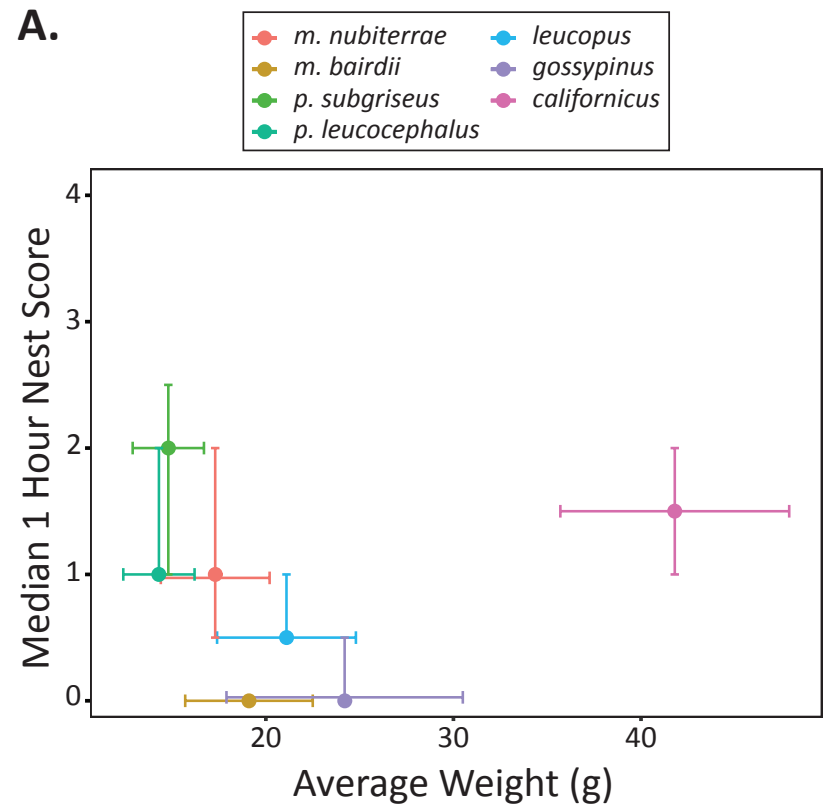

B.
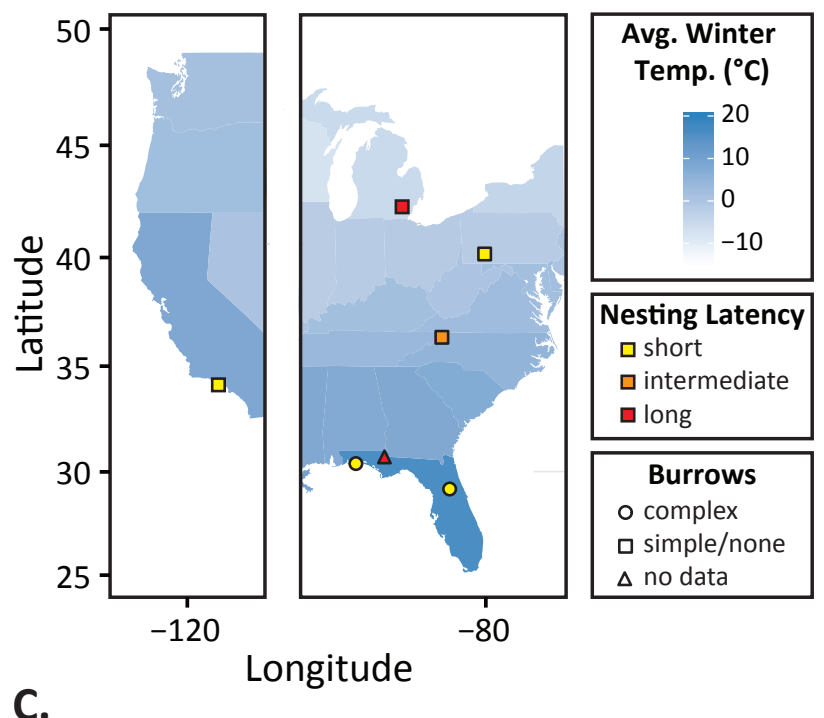

\section{Burrows}

o complex

口 simple/none

$\Delta$ no data

C.

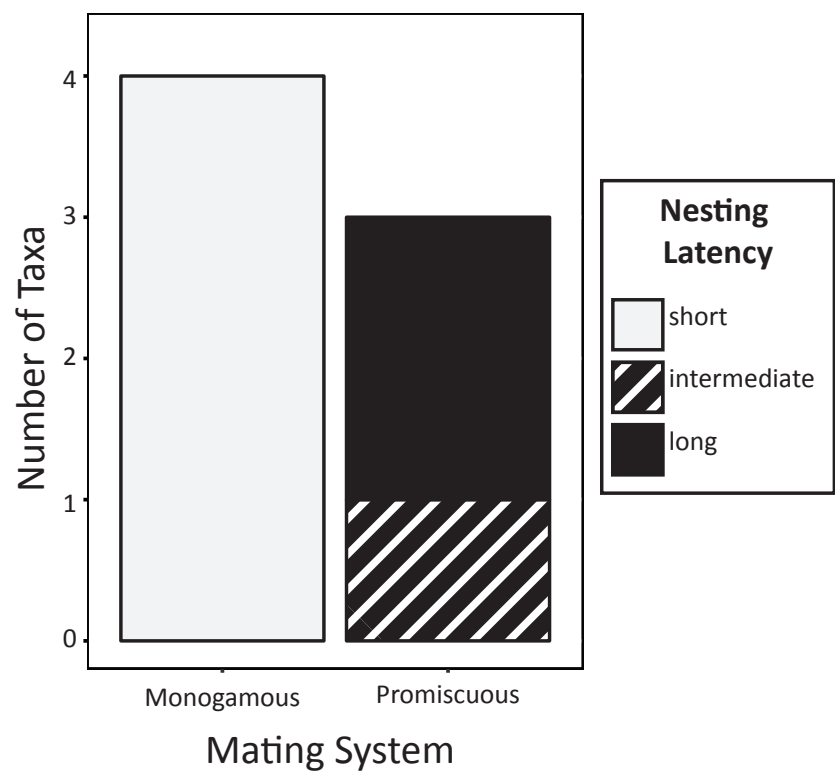

Figure 4: Environmental Factors and Nesting Behaviour 
Figure 4: Environmental factors and nesting behaviour. (A) Species median $1 \mathrm{~h}$ nest scores and average weight are plotted with bars indicating interquartile range (nest score) and standard deviation (weight). (B) Sites of colony origin (on US map), burrow shape (by symbol), and nesting latency (by colour) are indicated for each taxon (following legend). Map colours represent average winter temperatures by state (Arguez et al., 2010). Nesting latency category (short, intermediate, long) was determined by the significant species groups depicted in Fig. 2B.

(C) Association between a taxon's mating system and nesting latency. 

character correlation test: $\mathrm{AIC}$ (independent model) $=21.97, \mathrm{AIC}$ (dependent model) $=23.88$, likelihood ratio=2.09, $P=0.35$ ). However, a model in which short nesting latency depends on mating system fits the observed data significantly better than a model assuming the two traits are independent (Table 2, Fig. other abiotic environmental factors we examined are not.

\section{DISCUSSION}

Nesting is important for survival in rodents, but it is not clear how this behaviour varies among species or which evolutionary pressures drive these changes. Here we designed a novel high-throughput phenotyping paradigm to evaluate variation in both nest structure and the timing of nesting behaviour in closely related species of deer mice. We found that Peromyscus mice are generally able to construct dome-shaped nests, but vary strikingly in their latency to do so. Because nesting latency is not simply correlated with phylogeny, this raises the possibility that natural selection may contribute to inter-taxon variation. When we tested for correlations between latency to nest and several abiotic and biotic variables, we found that mating system, but surprisingly not climate or body size, is correlated with nesting behaviour.

Nesting has been well studied in laboratory models (e.g. Lisk et al., 1969; Lynch, 1980).

However, the majority of these nesting experiments, including some studies in Peromyscus, measure the 307 amount of nesting material that an animal pulls into its cage or the final nest structure achieved over a 308 24-hour period (Hartung et al., 1979; King et al., 1964; Layne, 1969; Lynch \& Hegmann, 1973). By 
310 just one hour after the replacement of nesting material, we are able to assess whether the animals

311 differ in their latency to begin nest construction - what might be considered a baseline motivation to

312 nest. This is complemented by a second measurement at the more permissive overnight time point,

313 which allows us to evaluate whether animals vary in their overall ability to build three-dimensional

314 structures. This novel phenotyping paradigm therefore allows us to distinguish between animals that

315 differ in their motivation to construct nests of similar shape from those that differ in their ability to

316 construct nests.

Using this approach, we find that even closely-related Peromyscus species vary dramatically in their latency to begin nesting, while variation in final nest structure is much more modest. This is in contrast to studies of nesting in birds and insects, where the structures of complete, species-typical nests are highly variable (Collias, 1964; Healy et al., 2008; Knerer et al., 2012; Price \& Griffith, 2017;

321 Schmidt, 1964), or even burrow construction in Peromyscus, where species excavate cavities that 322 significantly differ in size and shape (Hu \& Hoekstra, 2017; Weber \& Hoekstra, 2009). The relative 323 conservation of nest structure implies that the ability to produce dome-shaped nests is important for 324 most animals in the genus. However, variation in latency to begin nesting suggests that prioritization of 325 the behaviour varies among taxa. These patterns also imply that variation in nesting in these mice is 326 likely due to altered motivation rather than changes in stereotyped motor patterns, morphology, or 327 target nest structure. 
1983). It is worth noting that the positive relationship between body weight and nest weight observed in

previous studies of rodent nesting (King et al., 1964; Lynch, 1992; Wolfe, 1970) might be at least partially this confounding factor.

341 (Wolfe, 1970) alter the amount of nesting material used by rodents in natural populations. However, we

342 find only modest variation in final nest shape and no evidence for a relationship between nesting

343 latency and average winter temperatures or latitude of origin, which is frequently used as a proxy for

344 temperature. Nor do we find evidence for an association between nesting latency and the construction

345 of elaborate burrows, which function as microclimates and buffer the animals from changes in ambient

346 temperature (Hayward, 1965; Sealander, 1952; Weber \& Hoekstra, 2009). Although these colonies have

347 experienced reduced selective pressure while bred in laboratory settings, there is still no evidence of an

348 association between climate/microclimate and latency when we consider only the colonies founded

349 within the past 10 years (Table 1; gossypinus, polionotus leucocephalus, and maniculatus nubiterrae).

350 Given that most of the variation we observe takes the form of prioritization differences rather than

351 changes in nest size or shape, it may be especially necessary to consider the broader behavioural

352 repertoire of these taxa, including biotic factors that could contribute to the motivation to nest.

353 While we do not observe a simple relationship between nesting behaviour and any of the abiotic

354 factors we examined, we do find an intriguing correlation between social environment and nesting

355 latency. With the caveats that our sample size is relatively low and that the classification of species as

356 monogamous or promiscuous relies on incomplete evidence, our results suggest that mating system and

357 nesting latency are not independent, with all putatively monogamous species having short latencies to 
nest. It is possible that this reflects a tendency to invest in a home territory that is more beneficial for

359 monogamous animals than for promiscuous ones (Gaulin \& FitzGerald, 1988), or that selection for

360 increased paternal care, a hallmark of monogamous mating systems (Kleiman, 1977), might result in

361 increased motivation to nest even in virgin animals. This potential relationship between social behaviour

362 and the prioritization of nesting behaviour underscores the importance of considering both biotic and

363 abiotic environment when investigating the causes of behavioural evolution.

\section{CONCLUSION}

Measurement of extended phenotypes such as nests allows us to study how behaviours evolve

367 within and between species. Here we showed that the ability to nest is relatively conserved in the genus

368 Peromyscus, but latency to begin nest construction is highly variable, even between sister species. This

369 suggests that evolution of nesting behaviour in these animals is characterized by differences in the

370 prioritization of an otherwise conserved behavioural pattern. Intriguingly, while abiotic environment

371 cannot explain these species differences in nesting behaviour, we find a correlation between latency to

372 nest and mating system, with monogamous species prioritizing nesting. Finally, as the innate differences

373 in nesting behaviour in Peromyscus appear to be largely changes in the motivation to nest, future

374 studies in this system may elucidate genetic and neurobiological mechanisms that lead to differences in

375 motivation to engage in particular behaviours, a topic with implications far beyond nesting behaviour. 


\section{ACKNOWLEDGEMENTS}

We would like to thank Harvard undergraduates A. Bielawski, M. Charifson, E. D’Agostino, M. Noriega, and J. Rhodes for blinded scoring of behavioural assays. N. Bedford and C. Hu assisted with the figures. L. Revell and O. Lapiedra provided advice on comparative methods. The Hoekstra lab provided helpful feedback on the experiments and figures, and N. Bedford, E. Hager, D. Haig, C. Hu, B. König, M. Noriega, K. Pritchett-Corning, and K. Turner commented on the manuscript. We would like to thank the Harvard OAR staff for their assistance with animal husbandry.

\section{Funding}

CLL was supported by a Morris E. Zuckerman Fellowship, a Smith Family Graduate Science and Engineering Fellowship, and the Harvard Molecules, Cells, and Organisms PhD Program. CLL received a Harvard Mind, Brain, and Behaviour Student Award. HEH is an Investigator of the Howard Hughes Medical Institute. This work was supported, in part, by a National Science Foundation Doctoral Dissertation Improvement Grant (DDIG). 


\section{REFERENCES}

Arguez, A., Durre, I., Applequist, S., Squires, M., Vose, R., Yin, X., \& Bilotta, R. (2010). NOAA's U.S. Climate Normals (1981-2010). (Publication no. DOI:10.7289/V5PN93JP). Retrieved 10/18/16, from NOAA National Centers for Environmental Information.

Bedford, N. L., \& Hoekstra, H. E. (2015). Peromyscus mice as a model for studying natural variation. Elife, 4, e06813.

Blair, W. F. (1950). Ecological factors in speciation of Peromyscus. Evolution, 4(3), 253-275.

Blair, W. F. (1951). Population structure, social behavior, and environmental relations in a natural population of the beach mouse (Peromyscus polionotus leucocephalus): University of Michigan Laboratory of Vertebrate Biology Contributions, 48, 1-47.

Bradley, R. D., Durish, N. D., Rogers, D. S., Miller, J. R., Engstrom, M. D., \& Kilpatrick, C. W. (2007). Toward a molecular phylogeny for Peromyscus: evidence from mitochondrial cytochrome- $b$ sequences. Journal of Mammalogy, 88(5), 1146-1159.

Bult, A., \& Lynch, C. B. (1997). Nesting and fitness: lifetime reproductive success in house mice bidirectionally selected for thermoregulatory nest-building behavior. Behavior Genetics, 27(3), 231-240.

Clark, F. H. (1936). Geotropic behavior on a sloping plane of arboreal and non-arboreal races of mice of the genus Peromyscus. Journal of Mammalogy, 17(1), 44-47.

Collias, N. E. (1964). The evolution of nests and nest-building in birds. American Zoologist, 4(2), 175-190.

Crook, J. H. (1963). A comparative analysis of nest structure in the weaver birds (Ploceinae) Ibis, 105(2), 238-262.

Crossman, C. A., Rohwer, V. G., \& Martin, P. R. (2011). Variation in the structure of bird nests between northern Manitoba and southeastern Ontario. PLOS ONE, 6(4), e19086.

Dawkins, R. (1982). The Extended Phenotype: The Long Reach of the Gene: Oxford University Press. 
401

402

403

404

405

406

407

408

409

410

411

412

413

414

415

416

417

418

419

420

421

422

Dawson, W. D., Lake, C. E., \& Schumpert, S. S. (1988). Inheritance of burrow building in Peromyscus. Behavior Genetics, 18(3), 371-382.

Dewey, M. J., \& Dawson, W. D. (2001). Deer mice: the Drosophila of North American mammalogy. Genesis, 29(3), 105-109.

Dewsbury, D. A., Baumgardner, D. J., Evans, R. L., \& Webster, D. G. (1980). Sexual dimorphism for body mass in 13 taxa of muroid rodents under laboratory conditions. Journal of Mammalogy, 61(1), 146-149.

Dooley, J. L., \& Dueser, R. D. (1990). An experimental examination of nest-site segregation by two Peromyscus species. Ecology, 71(2), 788-796.

Gaulin, S., \& FitzGerald, R. W. (1988). Home-range size as a predictor of mating systems in Microtus. Journal of Mammalogy, 69(2), 311-319.

Grafen, A. (1989). The phylogenetic regression. Philosophical Transactions of the Royal Society of London. B , 326(1233), 119-157.

Glaser, H. \& Lustick, S. (1975). Energetics and nesting behavior of the northern white-footed mouse, Peromyscus leucopus noveboracensis. Physiological Zoology, 48(2), 105-113.

Hansell, M. H. (1984). Animal Architecture and Building Behaviour: Longman Press.

Hansell, M. H. (2005). Animal Architecture: Oxford University Press.

Hartung, T. G., \& Dewsbury, D. A. (1979). Nest-building behavior in seven species of muroid rodents. Behavioral and Neural Biology, 27(4), 532-539.

Hayward, J. S. (1965). Microclimate temperature and its adaptive significance in six geographic races of Peromyscus. Canadian Journal of Zoology, 43(2), 341-350.

Healy, S., Walsh, P., \& Hansell, M. (2008). Nest building by birds. Current Biology, 18(7), R271-R273. 
423

424

425

426

427

428

429

430

431

432

433

434

435

436

437

438

439

440

441

442

443

444

445

Hess, S. E., Rohr, S., Dufour, B. D., Gaskill, B. N., Pajor, E. A., \& Garner, J. P. (2008). Home improvement: C57BL/6J mice given more naturalistic nesting materials build better nests. Journal of the American Association for Laboratory Animal Science, 47(6), 25-31.

Hill, R. W. (1983). Thermal physiology and energetics of Peromyscus: Ontogeny, body temperature, metabolism, insulation, and microclimatology. Journal of Mammalogy, 64(1): 19-37.

Hu, C. K., \& Hoekstra, H. E. (2017). Peromyscus burrowing: a model system for behavioral evolution. Seminars in Cell \& Developmental Biology, 61, 107-114.

Ivey, R. D. (1949). Life history notes on three mice from the Florida east coast. Journal of Mammalogy, $30(2), 157-162$.

Jašarević, E., Bailey, D. H., Crossland, J. P., Dawson, W. D., Szalai, G., Ellersieck, M. R., Rosenfeld, C. S., \& Geary, D. C. (2013). Evolution of monogamy, paternal investment, and female life history in Peromyscus. Journal of Comparative Psychology, 127(1), 91-102.

King, J. A., Maas, D., \& Weisman, R. (1964). Geographic variation in nest size among species of Peromyscus. Evolution, 18(2),230-234.

Kleiman, D. G. (1977). Monogamy in mammals. The Quarterly Review of Biology, 52(1), 39-69.

Klein, H. G., \& Layne, J. N. (1978). Nesting behavior in four species of mice. Journal of Mammalogy, 59(1), 103-108.

Knerer, G., \& Atwood, C. E. (2012). Nest architecture as an aid in Halictine taxonomy (Hymenoptera: Halictidae). The Canadian Entomologist, 98(12), 1337-1339.

Lackey, J. A., Huckaby, D. G., \& Ormiston, B. G. (1985). Peromyscus leucopus. Mammalian Species Archive, 247, 1-10.

Layne, J. N. (1969). Nest-building behavior in three species of deer mice, Peromyscus. Behaviour, 35(3), 288-302. 
Layne, J. N. \& Dolan, P. G. (1975). Thermoregulation, metabolism, and water economy in the golden mouse (Ochroyomys nuttalli). Comparative Biochemistry and Physiology Part A: Physiology, 52(1), 153-163.

Lisk, R. D., Pretlow , R. A., \& Friedman, S. M. (1969). Hormonal stimulation necessary for elicitation of maternal nest-building in the mouse (Mus musculus). Animal Behaviour, 17(4), 730-737.

Lynch, C. B. (1980). Response to divergent selection for nesting behavior in Mus musculus. Genetics, 96(3), 757-765.

Lynch, C. B. (1992). Clinal variation in cold adaptation in Mus domesticus: verification of predictions from laboratory populations. The American Naturalist, 139(6), 1219-1236.

Lynch, C. B., \& Hegmann, J. P. (1973). Genetic differences influencing behavioral temperature regulation in small mammals. II. Genotype-environment interactions. Behavior Genetics, 3(2), 145-154.

Lynch, C. B., \& Possidente, B. P. (1978). Relationships of maternal nesting to thermoregulatory nesting in house mice (Mus musculus) at warm and cold temperatures. Animal Behaviour, 26, 1136-1143.

M'Closkey, R. T. (1976). Community structure in sympatric rodents. Ecology, 57(4), 728-739.

Mainwaring, M. C., Hartley, I. R., Lambrechts, M. M., \& Deeming, D. C. (2014). The design and function of birds' nests. Ecology and Evolution, 4(20), 3909-3928.

McCarley, W. (1959). A study of the dynamics of a population of Peromyscus gossypinus and $P$. nuttalli subjected to the effects of X-irradiation. American Midland Naturalist, 61(2), 447-469.

Merritt, J. F. (1974). Factors influencing the local distribution of Peromyscus californicus in Northern California. Journal of Mammalogy, 55(1), 102-114.

Merritt, J. F. (1978). Peromyscus californicus. Mammalian Species (85), 1-6.

Meserve, P. L. (1977). Three-dimensional home ranges of cricetid rodents. Journal of Mammalogy, 58(4), 549-558. 
Morris, J. G., \& Kendeigh, S. C. (1981). Energetics of the prairie deer mouse Peromyscus maniculatus bairdii. American Midland Naturalist, 105(2), 368-376.

Ogilvie, D. M., \& Stinson, R. H. (1966). Temperature selection in Peromyscus and laboratory mice, Mus musculus. Journal of Mammalogy, 47(4), 655-660.

Pagel, M. (1994). Detecting correlated evolution on phylogenies: a general method for the comparative analysis of discrete characters. Proceedings of the Royal Society of London B,255(1342), 37-45.

Paradis E., Claude, J. \& Strimmer, J. (2004). APE: analyses of phylogenetics and evolution in R language. Bioinformatics, 20, 289-290.

Pearson, O. P. (1960). The oxygen consumption and bioenergetics of harvest mice. Physiological Zoology, 33(2), 152-160.

Pearson, P. G. (1953). A field study of Peromyscus populations in Gulf Hammock, Florida. Ecology, 34(1), 199-207.

Pinheiro, J., Bates, D., DebRoy, S., Sarkar, D., \& Team, R. C. (2017). nlme: Linear and Nonlinear Mixed Effects Models (Version R package version 3.1-131).

Price, J. J., \& Griffith, S. C. (2017). Open cup nests evolved from roofed nests in the early passerines. Proceedings of the Royal Society B, 284(1848), online early edition.

Revell, L. J. (2012). phytools: An R package for phylogenetic comparative biology (and other things). Methods in Ecology and Evolution, 3, 217-223.

Schmidt, R. S. (1964). Apticotermes nests. American Zoologist, 4(2), 221-225.

Sealander, J. A. (1952). The relationship of nest protection and huddling to survival of Peromyscus at low temperature. Ecology, 33(1), 63-71.

Southwick, C. H. (1955). Regulatory mechanisms of house mouse populations: social behavior affecting litter survival. Ecology, 36(4), 627-634. 
492

493

494

495

496

497

498

499

500

501

502

503

504

505

506

507

508

509

510

511

512

513

514

Sumner, F. B. (1926). An analysis of geographic variation in mice of the Peromyscus polionotus group from Florida and Alabama. Journal of Mammalogy, 7(3), 149-184.

Symonds, M. R. E., \& Blomberg, S. P. (2014). A primer on phylogenetic generalised least squares. In L. Z. Garamszegi (Ed.), Modern Phylogenetic Comparative Methods and Their Application in Evolutionary Biology: Concepts and Practice (pp. 105-130). Berlin, Heidelberg: Springer Berlin Heidelberg.

Turner, L. M., Young, A. R., Römpler, H., Schöneberg, T., Phelps, S. M., \& Hoekstra, H. E. (2010). Monogamy evolves through multiple mechanisms: evidence from V1aR in deer mice. Molecular Biology and Evolution, 27(6), 1269-1278.

Vogt, F. D., \& Lynch, G. R. (1982). Influence of ambient temperature, nest availability, huddling, and daily torpor on energy expenditure in the white-footed mouse Peromyscus leucopus. Physiological Zoology, 55(1), 56-63.

Weber, J. N., \& Hoekstra, H. E. (2009). The evolution of burrowing behaviour in deer mice (genus Peromyscus). Animal Behaviour, 77(3), 603-609.

Winkler, D. W., \& Sheldon, F. H. (1993). Evolution of nest construction in swallows (Hirundinidae): a molecular phylogenetic perspective. Proceedings of the National Academy of Sciences, 90(12), 5705-5707.

Wolfe, J. L. (1970). Experiments on nest-building behaviour in Peromyscus (Rodentia: Cricetinae). Animal Behaviour, 18, 613-615.

Wolfe, J. L., \& Linzey, A. V. (1977). Peromyscus gossypinus. Mammalian Species, (70), 1-5.

Wolff, J. O., \& Cicirello, D. M. (1991). Comparative paternal and infanticidal behavior of sympatric whitefooted mice (Peromyscus leucopus noveboracensis) and deermice (P. maniculatus nubiterrae). Behavioral Ecology, 2(1), 38-45. 
bioRxiv preprint doi: https://doi. org/10.1101/177782. this version posted January 27,2018 . The copyright holder for this preprint (which was not certified by peer review) is the author/funder, who has granted bioRxiv a license to display the preprint in perpetuity. It is made available under aCC-BY-NC-ND 4.0 International license.

515 Wolff, J. O., \& Durr, D. S. (1986). Winter nesting behavior of Peromyscus leucopus and Peromyscus

516 maniculatus. Journal of Mammalogy, 67(2), 409-412.

517 Wolff, J. O., \& Hurlbutt, B. (1982). Day refuges of Peromyscus leucopus and Peromyscus maniculatus. Journal of Mammalogy, 63(4), 666-668. 


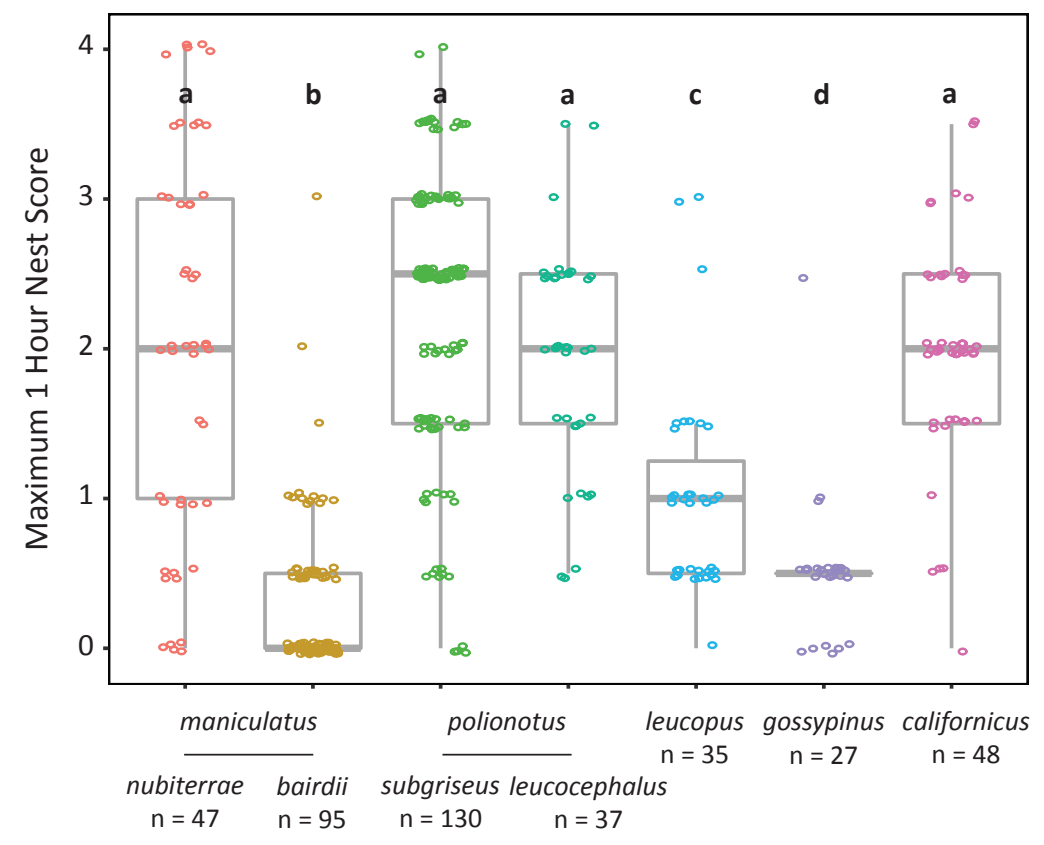

Species

Supplemental Figure S1: Maximum 1 hour nest scores. Maximum nest score achieved $1 \mathrm{~h}$ after receiving new nesting material over the 3 trial days. Letters indicate species groups that did not significantly differ from one another, while all other pairwise comparisons were significant (Wilcoxon rank-sum test, Bonferroni-corrected $P<0.05$ ), largely consistent with median scores (Fig. 2B, Supplemental Table S2), with the exception of a significant difference in maximum scores between $P$. gossypinus and $P$. $m$. bairdii animals (Wilcoxon rank-sum test, Bonferroni-corrected $P=0.049$ ). Sample sizes provided below. 
bioRxiv preprint doi: https://doi.org/10.1101/177782; this version posted January 27,2018 . The copyright holder for this preprint (which was not certified by peer review) is the author/funder, who has granted bioRxiv a license to display the preprint in perpetuity. It is made available under aCC-BY-NC-ND 4.0 International license.

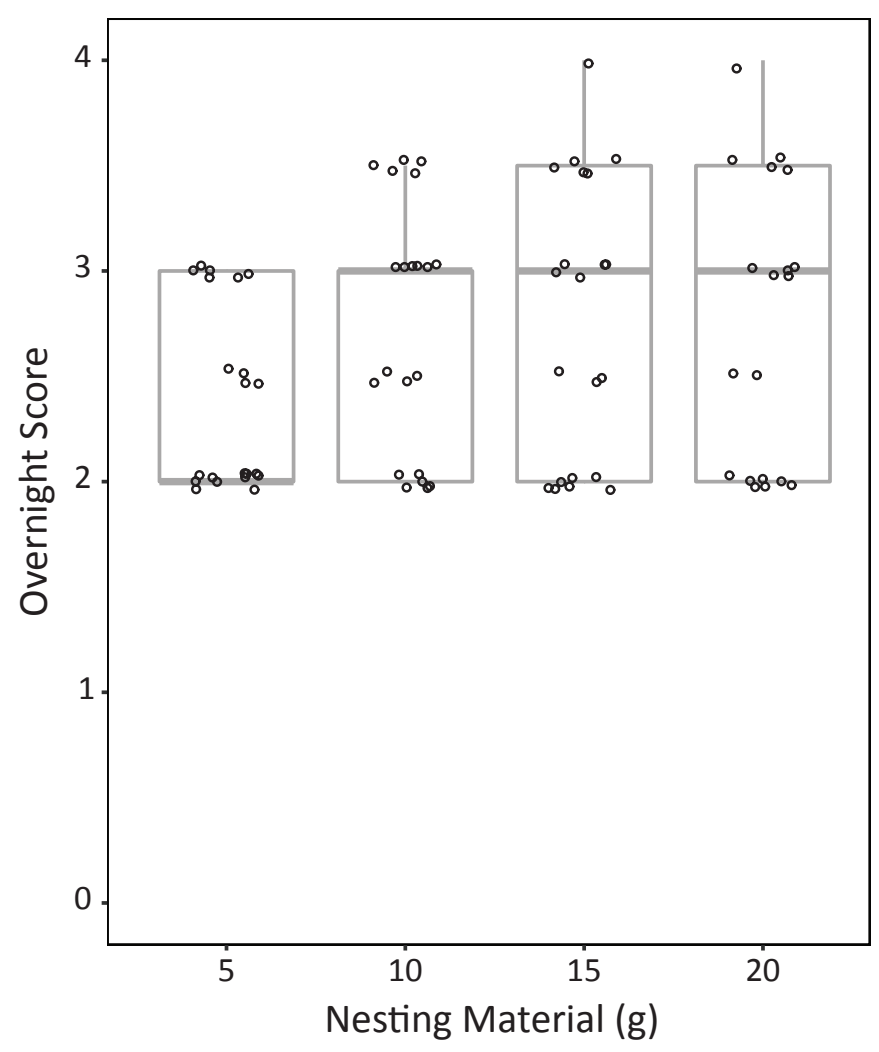

Supplemental Figure S2: Effect of increasing nesting material in $\boldsymbol{P}$. californicus. Adult animals $(N=21)$ were given increasing amounts of nesting material $(5 \mathrm{~g}, 10 \mathrm{~g}, 15 \mathrm{~g}$ and $20 \mathrm{~g}$ ) on 4 sequential days. Higher amounts of nesting material increased overnight nest scores (Friedman repeated measures test, $P=0.003$ ). 
bioRxiv preprint doi: https://doi.org/10.1101/177782; this version posted Januarv 27. 2018. The copvriaht holder for this preprint (which was not certified by peer review) is the author/funder, who has granted bioRxiv a license to display the preprint in perpetuity. It is made available under aCC-BY-NC-ND 4.0 International license.

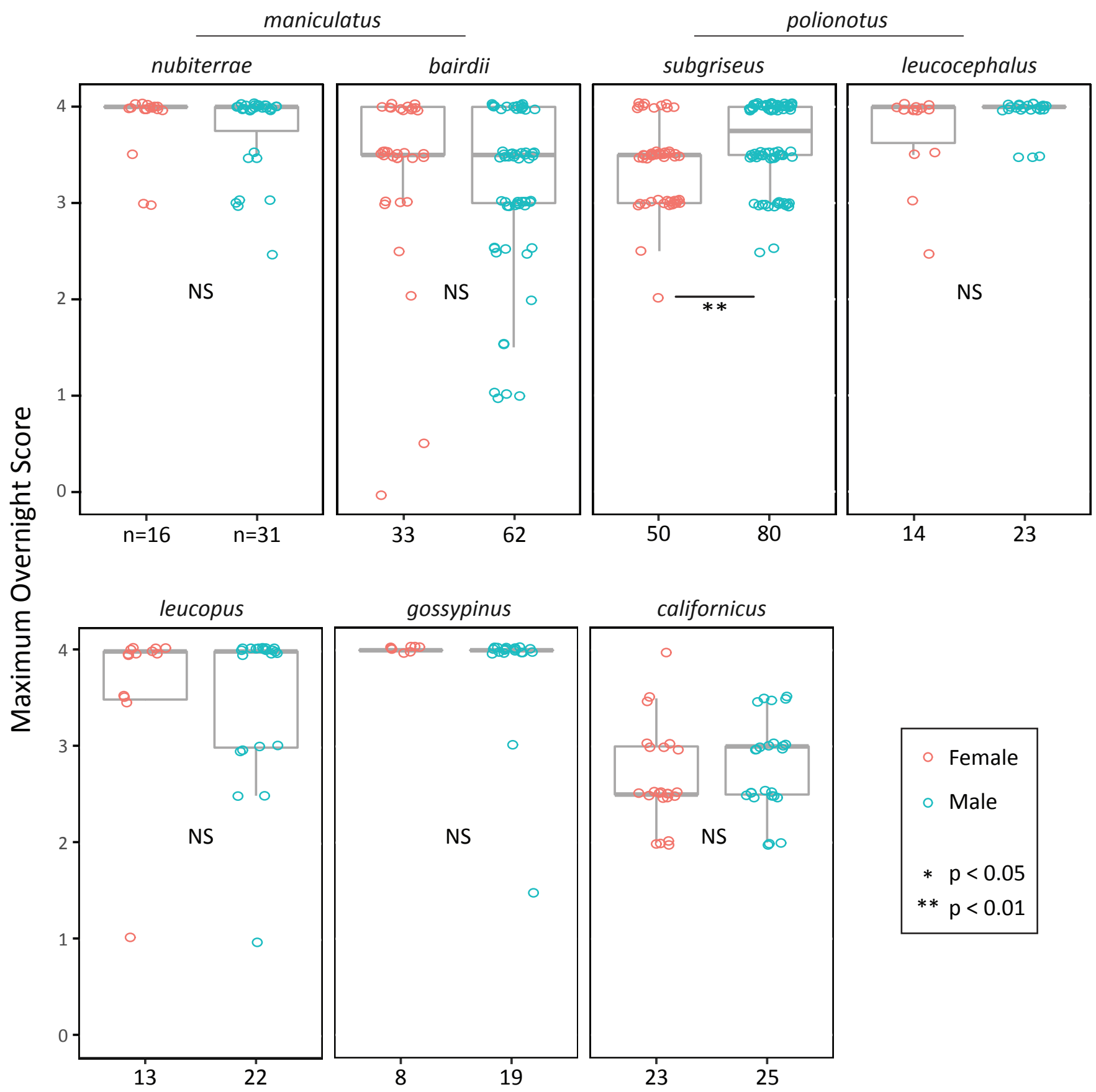

Supplemental Figure S3: Sex differences in maximum overnight nest scores. Evidence for a significant sex difference overnight nest score occurred in only one taxon: in $P$. polionotus subgriseus, males built higher scoring nests at the overnight time point than females (Wilcoxon rank-sum test, Bonferroni-corrected $P=0.008)$. Sample sizes are provided below. NS = not significant. 
polionotus

A.

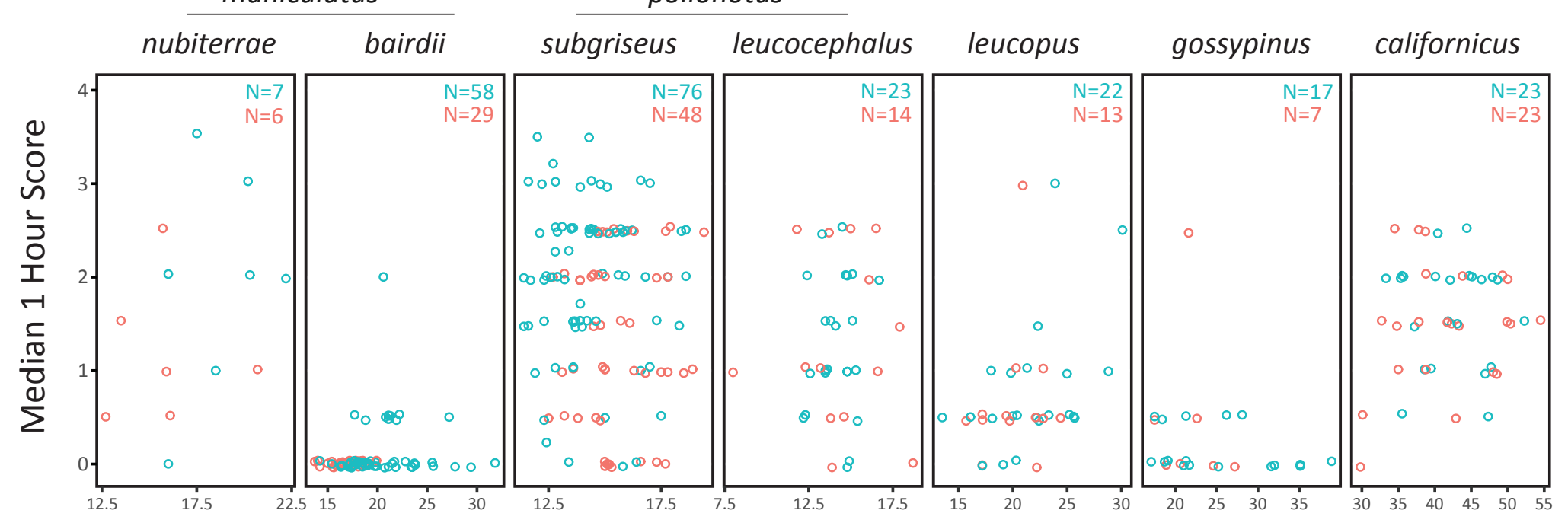

B.
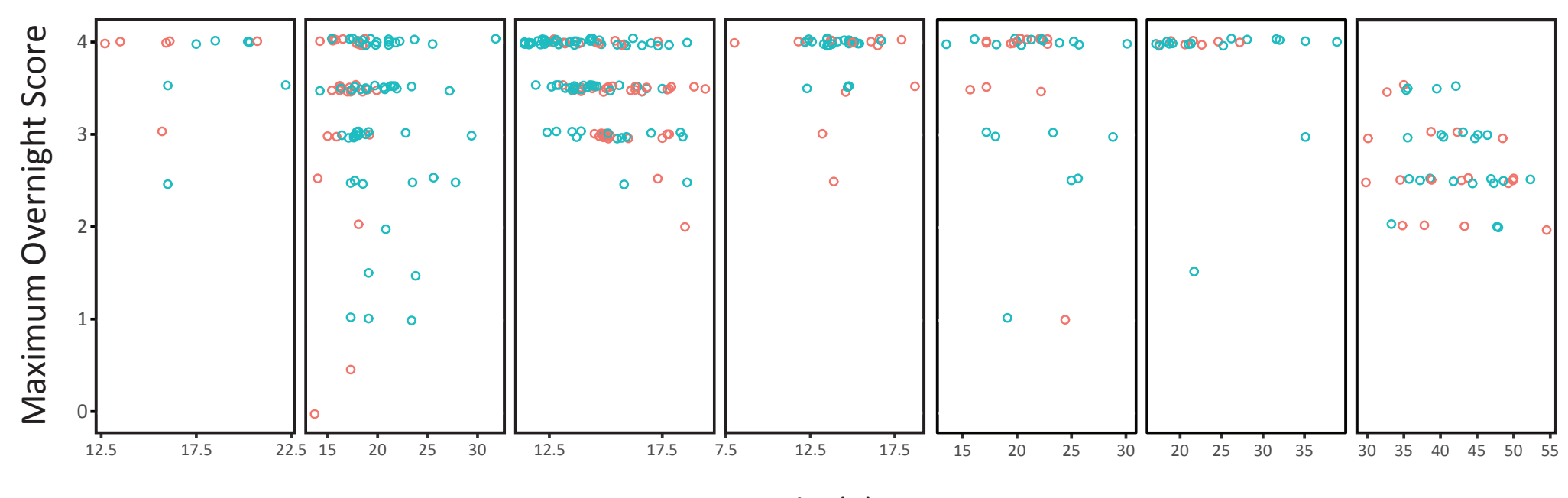

\section{Weight (g)}

\section{- Male o Female}

Supplemental Figure S4: Effect of body weight on nesting behaviour by species and sex. (A) Median nest scores at $1 \mathrm{~h}$ were not correlated with weight within any species-sex group (Spearman correlation, Bonferroni-corrected $P>0.05$ ). (B) Overnight maximum nest scores were not correlated with weight within any species-sex group (Spearman correlation, Bonferroni-corrected $P>0.05$ ). Note different $x$-axis for each species as indicated. Sample sizes are provided by sex and were the same for both time points. 
Supplemental Table S1: Detailed Nest Scoring Criteria

\begin{tabular}{|c|c|c|c|c|c|}
\hline Score & Score Description & Shredding & Nest Site $^{1}$ & Walls $^{2}$ & Overhead Cover \\
\hline 0 & No Manipulation & None & - & - & - \\
\hline 0.5 & Minor Shredding & $\begin{array}{c}\text { Minor: } \\
\text { Stop of } 1 \text { nestlet }\end{array}$ & - & - & - \\
\hline 1 & Extensive Shredding & $\begin{array}{l}\text { Extensive: } \\
>\text { top of } 1 \\
\text { nestlet }\end{array}$ & $\begin{array}{l}\text { No: } \\
\text { neither a nor } b \text { is } \\
\text { true }\end{array}$ & No & - \\
\hline 1.5 & Ambiguous Nest Site & Extensive & $\begin{array}{l}\text { Unclear: } \\
\text { either a OR } b \text { is } \\
\text { true }\end{array}$ & No & - \\
\hline 2 & Platform Nest & - & $\begin{array}{l}\text { Yes: both a and } \\
\text { b are true }\end{array}$ & $\begin{array}{c}\text { No: }<1 / 2 \text { sphere height for }<1 / 2 \\
\text { circumference }\end{array}$ & - \\
\hline 2.5 & Partial Cup Nest & - & Yes & $\begin{array}{l}\text { Partial: }<1 / 2 \text { sphere height for }> \\
1 / 2 \text { circumference } O R \geq 1 / 2 \text { sphere } \\
\text { height for }<1 / 2 \text { of circumference }\end{array}$ & - \\
\hline 3 & Cup Nest & - & Yes & $\begin{array}{l}\text { Yes: } \\
\geq 1 / 2 \text { sphere height for } \geq 1 / 2 \\
\text { circumference }\end{array}$ & no overhead cover \\
\hline 3.5 & Partial Dome Nest & - & Yes & Yes & $\begin{array}{c}\text { Partial: }<50 \% \text { of the } \\
\text { sphere is covered or there } \\
\text { are multiple entrance } \\
\text { holes }\end{array}$ \\
\hline 4 & Full Dome Nest & - & Yes & Yes & $\begin{array}{l}\text { Yes: } \geq 50 \% \text { of the sphere } \\
\text { is covered and there is at } \\
\text { most one entrance hole }\end{array}$ \\
\hline
\end{tabular}

1. A nest site is defined according to two criteria: (a) there is a contiguous concentration of nestlet around a central point consisting of $\geq 90 \%$ of any material the animal has shredded, and (b) the shape of the putative nest site is defined by the shredded material ( $>50 \%$ of the nestlet at the nest site is shredded).

2. To evaluate walls, imagine that the nest cavity is filled by a sphere, sensu (Hess et al., 2008). The walls are compared to the height of the sphere within the cavity, and the proportion of the circumference of the sphere that is surrounded by walls is noted. 
Supplemental Table S2: Pairwise species comparisons of $1 \mathrm{hr}$ median and overnight maximum scores

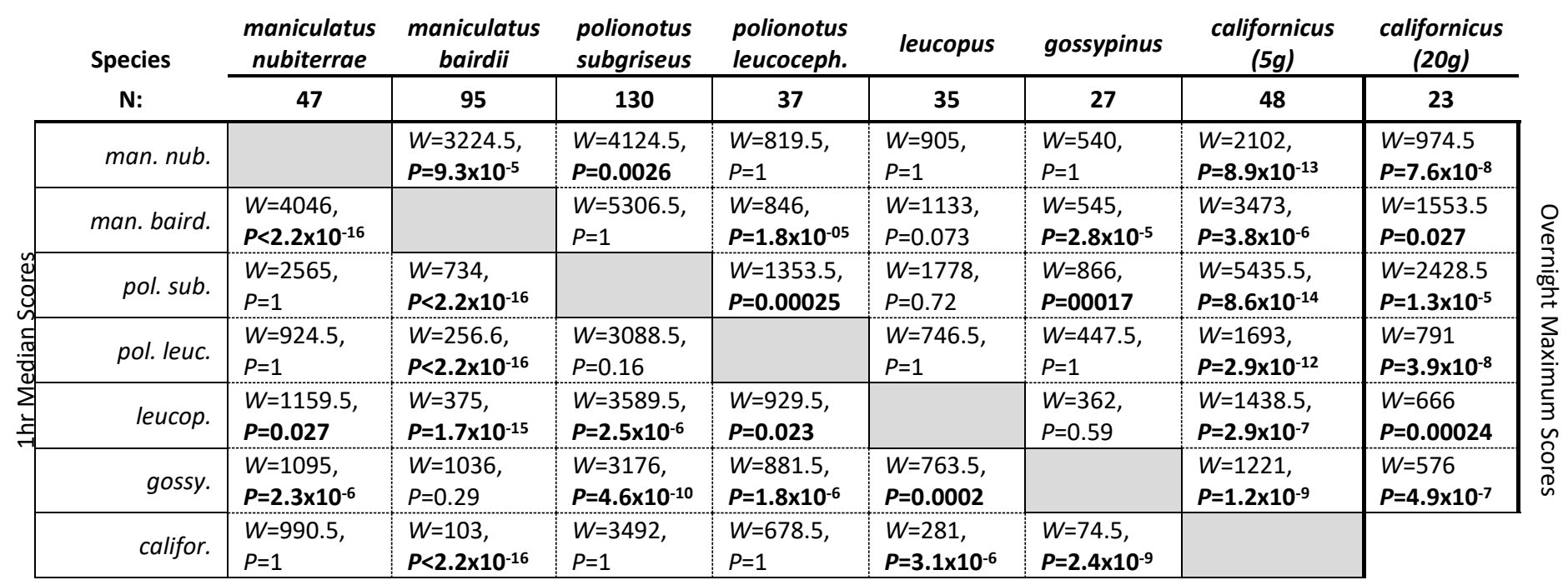

The results of pairwise Wilcoxon rank-sum tests for species differences in median $1 \mathrm{hr}$ scores (below diagonal) or maximum overnight scores (above diagonal). For each comparison, test statistics (W) and Bonferroni-corrected $p$-values are reported; significant results $(p<0.05)$ are in bold. 
Supplemental Table S3: Sex differences in nest scores

\begin{tabular}{|c|c|c|c|c|}
\hline Taxon & Males & Females & 1hr Median Score & $\begin{array}{c}\text { Maximum } \\
\text { Overnight Score }\end{array}$ \\
\hline maniculatus nubiterrae & 31 & 16 & $W=119.5, P=0.03$ & $W=266, P=1$ \\
\hline maniculatus bairdii & 62 & 33 & $W=858, P=0.11$ & $W=1173, P=1$ \\
\hline polionotus subgriseus & 80 & 50 & $W=1262.5, P=0.002$ & $W=1361, P=0.008$ \\
\hline polionotus leucocephalus & 23 & 14 & $W=163.5, P=1$ & $W=133, P=1$ \\
\hline leucopus & 22 & 13 & $W=125.5, P=1$ & $W=152, P=1$ \\
\hline gossypinus & 19 & 8 & $W=87, P=1$ & $W=84, P=1$ \\
\hline californicus & 25 & 23 & $W=219.5, P=1$ & $W=238.5, P=1$ \\
\hline
\end{tabular}

The results of pairwise Wilcoxon rank-sum tests for sex differences in $1 \mathrm{hr}$ median nest scores or maximum overnight nest scores. Sample sizes, test statistics (W), and Bonferroni-corrected $p$-values are reported; significant results $(P<0.05)$ are in bold. 
Supplemental Table S4: Spearman correlations between weight and nest scores within species/sex groups

Weight vs. 1hr Median Score

\begin{tabular}{|c|c|c|c|c|}
\hline & \multicolumn{2}{|c|}{ Weight vs. 1hr Median Score } & \multicolumn{2}{|c|}{ Weight vs. Maximum Overnight Score } \\
\hline Taxon & Males & Females & Males & Females \\
\hline $\begin{array}{c}\text { maniculatus } \\
\text { nubiterrae }\end{array}$ & $r_{\mathrm{s}}=0.24, N=7, P=1$ & $r_{\mathrm{s}}=-0.09, N=6, P=1$ & $r_{\mathrm{s}}=0.39, N=7, P=1$ & $r_{\mathrm{s}}=0.13, N=6, P=1$ \\
\hline $\begin{array}{c}\text { maniculatus } \\
\text { bairdii }\end{array}$ & $r_{\mathrm{s}}=0.22, N=58, P=1$ & $N=29$, see below & $r_{\mathrm{s}}=0.07, N=58, P=1$ & $r_{\mathrm{s}}=0.13, N=29, P=1$ \\
\hline $\begin{array}{l}\text { polionotus } \\
\text { subgriseus }\end{array}$ & $r_{\mathrm{s}}=0.01, N=76, P=1$ & $r_{\mathrm{s}}=0.04, N=48, P=1$ & $\begin{array}{c}r_{\mathrm{s}}=-0.32, N=76, \\
P=0.08\end{array}$ & $\begin{array}{c}r_{\mathrm{s}}=-0.31, N=48, \\
P=0.48\end{array}$ \\
\hline $\begin{array}{c}\text { polionotus } \\
\text { leucocephalus }\end{array}$ & $r_{\mathrm{s}}=0.03, N=23, P=1$ & $\begin{array}{c}r_{\mathrm{s}}=-0.10, N=14, \\
P=1\end{array}$ & $r_{\mathrm{s}}=0.11, N=23, P=1$ & $\begin{array}{c}r_{\mathrm{s}}=-0.06, N=14 \\
P=1\end{array}$ \\
\hline leucopus & $\begin{array}{c}r_{\mathrm{s}}=0.41, N=22, \\
P=0.82\end{array}$ & $r_{\mathrm{s}}=0.22, N=13, P=1$ & $\begin{array}{c}r_{\mathrm{s}}=-0.08, N=22, \\
P=1\end{array}$ & $\begin{array}{c}r_{\mathrm{s}}=-0.04, N=13 \\
P=1\end{array}$ \\
\hline gossypinus & $\begin{array}{c}r_{\mathrm{s}}=-0.25, N=17, \\
P=1\end{array}$ & $r_{\mathrm{s}}=-0.24, N=7, P=1$ & $\begin{array}{c}r_{\mathrm{s}}=-0.23, N=17, \\
P=1\end{array}$ & $N=7$, see below \\
\hline californicus & $\begin{array}{c}r_{\mathrm{s}}=-0.08, N=23 \\
P=1\end{array}$ & $r_{\mathrm{s}}=0.14, N=23, P=1$ & $\begin{array}{c}r_{\mathrm{s}}=-0.36, N=23, \\
P=1\end{array}$ & $\begin{array}{c}r_{\mathrm{s}}=-0.29, N=23, \\
P=1\end{array}$ \\
\hline
\end{tabular}

Sample sizes, Spearman correlation coefficient $\left(r_{s}\right)$, and Bonferroni-corrected $p$-values are reported. Sample sizes are smaller than for other tests due to missing weight data. We were unable to perform correlations between $1 \mathrm{hr}$ scores and weight within maniculatus bairdii females because all 29 animals received a median score of 0 at 1 hour. Similarly, all female gossypinus animals produced maximum scores of 4 at the overnight time point. 